[Vicino Oriente XXIII (2019), pp. 121-138]

\title{
MIIROSAN TO KHURASAN: \\ HUNS, ALKHANS AND THE CREATION OF EAST IRAN
}

\author{
Khodadad Rezakhani - Princeton University
}

\begin{abstract}
Khurasan emerged in the medieval Islamic world, particularly after the 'Abbasid Revolution' of 750, as one of the major centres of power and influence in the domains of the Abbasid Caliphate. While most studies consider this from the point of view of Islamic history, the roots of the rise of this region goes back to the late antique period. This article studies the emergence of the region throughout the first millennium by considering the history of the region under the Kushan, KushanoSasnaian, Kidarite, Alkhan, Hephthalite, and Western Turk rule. By considering numismatic evidence, Bactrian documents, and epigraphic sources, the article develops the idea that the region emerged as an independent and culturally central area during the Kushan and immediate postKushan period and became the center of a political and cultural production, which eventually entered the pages of history in the early Islamic period.
\end{abstract}

Keywords: East Iran; Khurasan; Miirosan; Islam; Kushans

Defining geographical spaces and their role in historical processes is an essential part of almost all historical enquiries. In many cases, the assumptions made about a historical region are based on understanding of that geography in a modern, nation-state based, context. In the study of medieval Islam and the Iranian/Persianate world, the term Khurasan and the geography it refers to has occupied a special place. Its importance in the medieval Islamic context is noted by a few monographs and studies, ${ }^{1}$ although the origins of the term and the conceptualisation of its geography is less scrutinised. The following, by providing a survey of historical references to the term Khurasan, as well as positing its borrowing from Bactrian Miirosan, provides a narrative of the development of the region as an autonomous centre of power. By also studying a few of the sources and contextualising them, it also hopes to bring attention to non-textual evidence such as the coins and their importance in understanding the development of the concept of Khurasan as a geo-political term.

\section{INTRODUCTION}

Khurasan and Khurasani as geographical and historical terms dominate the early medieval Islamic sources. This is mainly because of the presence of the troops of Abu Muslim, a sometimes governor of Marv, the capital of Islamic Khurasan, who in $750 \mathrm{CE}$, swept through Iran and decimated the Umayyad armies, bringing the Caliphate to the 'Abbasid house. The rise of the Abbasids then is practically synonymous with the entry of the Khurasani soldiers into the politics of the Abbasid court and their dominance in the first hundred years of the dynasty's control. ${ }^{2}$ Similarly, Khurasan's exit from the direct control

See Daniel 1979; 1995, as well as Rante 2015 for a fresh archaeological view.

Various studies of the revolt of Abu Muslim and the rise of the Abbasids are available. Among these, Shaban 1970 was a novel approached, paying special attention to the local Khurasani context, although he gets much of the Hephthalite history wrong, probably because most of his information was based on Gibb 1923. Since Shaban, great studies on Khurasan and its place in the Abbasid Revolution, have become available, including

ISSN 0393-0300

e-ISSN 2532-5159

Rivista Open Access 
of the Caliph of Baghdad, under the leadership of the Samanids in the $10^{\text {th }}$ century, contributed in a major fashion to the decline of the Caliphate and its decay as the puppets of the Buyids, Hamdanis, and other 'Iraqi political units." Against this political background, the question that begs answering is the one about the origins of Khurasan. This is an illdefined geographical and political region on the extreme northeast of the Iranian Plateau and Transoxiana, touching the Pamirs, and at various times encompassing different parts of the 'Islamic East'. What, indeed, was the process through which various regions of Central Asia and East Iran became part of the uniform concept of Khurasan, representing soldiers and leaders of numerous ethnicities, languages, and religious and political identities? Perhaps not less importantly, where did the term Khurasan, and thus the identity associated with it, come from? ${ }^{4}$ The present paper, relying on advancements made in the historical studies of this region, will try to answer aspects of these questions and suggest interpretations. These might eventually lead us to better understand the origins of Khurasan as a geographical and historical unit and its role in the medieval Islamic world.

\section{KHURASAN IN EARLY ISLAMIC GEOGRAPHY}

1. Ibn Khurradadhbih, author of perhaps the oldest extant Arabic geographical treatise (middle of the $9^{\text {th }}$ century AD) began his description of the regions of the east with the province of Khurasan: "the East, which is a quarter of the domain, and starts with a description of Khurasan". 5 In this account, Ibn Khurradadbih divides Khurasan itself into four quarters - perhaps reflecting the Sasanian quadripartite division of their empire (alTabari, I.894). He also tells us that the entire province is governed by a "Bādūsbān who is its Isfahbid". ' According to Ibn Khurradadbih, each quarter of Khurasan has one Marzbān (marcher lord/military governor) ${ }^{7}$ and these are as follows:

«...a quarter is under the control of the Marzban of Marv Shahijan ${ }^{8}$ and its environs, one quarter under the control of the Marzban of Balkh and Tukharistan, one quarter under the control of the Marzban of Harat and Bushanj and Badghish (sic.) and

Daniel 1979; 1995, as well as Marin-Guzman 1994. De la Vaissière 2007a is the most recent work on Central Asian actors in the Abbasid state.

For the period of Abbasid power and centralised control of the lands of the east, see Bennison 2014. Kennedy 1986 covers the same turf in a classical study, but also tackles the following period, particularly after 861, and rise of powers such as the Hamdanids and the Buyids as well.

4 De la Vaissière (ed.) 2008 addresses the presence of the different communities and groups in the region and the different processes through which they converted to Islam Similarly, in his 2007 contribution, he addresses the presence of Central Asians in the Abbasid court and cuts through the regular understanding of them under the general rubric of the "Turks".

De Goeje $1889,18$.

6 Baduspan here is the Arabic rendering of Middle Persian pādūspān, mentioned by al-Tabari (I.894) and others as the alternative name for the commander of each of the four quarters. It is also the name of the ancestor of the Paduspanid ispahbids of Tabaristan in the early Islamic period (Madelung 1988).

7 Cf. Hudūd al-Alam, where the Maliks (kings) of Khurasan, of the Sāmān family, have their "margraves" (mulūk al-Atrāf) around Khurasan (Minorsky 1937, 102).

8 This is the more famous of the two Marv/Mervs both located in the Bactro-Margiana region. The other one, further east and south, is Marv-ur-Rūd, present day Bala Murghab, in north-western Afghanistan. 
Sajistan... and one quarter under the control of the Marzban of Mawara unNahr/Transoxiana».

Ibn Khurradadbih's definition of Khurasan, then, reflects at a maximalist position, considering even Sajistan/Sīstān, the area to the south of the Hindukush and on the delta of the Helmand River, as well as the entire Transoxiana, to be part of Khurasan. In contrast,

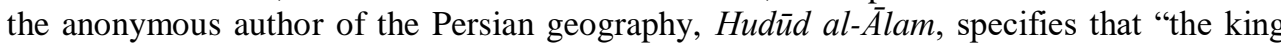
(pādšāh-i) Khorāsān in the days of the old was distinct from that of Transoxiana, but now they are one", 10 showing the recent addition of Transoxiana to the concept of Khurasan. Almost all authorities consider Balkh and Tukharistan as one of the four divisions of Khurasan; something that will be elaborated upon further below.

2. Another geographer, Ibn Hauqal, a famous traveller and geographer and writing a century after Ibn Khurradadbih, considers Khurasan to be the name of one of the seven climes (Ar. iqlimm) and provides a detailed description of what he considers to be part of Khurasan. In this description, however, Sajistan/Sīstān and Transoxiana are not counted. ${ }^{11}$

3. In these cases, and in other Medieval Middle Eastern references, the use of the term Khurāsān for the region, linguistically harkens back to the Sasanian use of the term Xwarāsān "East, Rising Sun" as the name of one of their four military Kust "sides" matching the cardinal points. ${ }^{12}$ The use of the term is confirmed by the seal evidence. ${ }^{13}$ These four kusts were established following the reforms of Kavad I and Khusrow I Anushervan in the early to mid-sixth century, ${ }^{14}$ after almost a century of Hephthalite threat against the eastern borders of the Sasanian Empire and the loss of much of the east at the end of the fifth century. ${ }^{15}$ But the use of the term in a Sasanian context itself is probably the result of the defeat of the Hephthalites at the hand of the Western Türk empire and the Sasanian recovery of the control of Balkh/Tukharistan, at least for a while. However, long before the use of the term by Muslim geographers, or even its use as a Sasanian administrative division, a similar term seems to have been used in the region, one that perhaps provides the background for the Sasanian Xwarāsān.

\section{THE BIRTH OF THE EAST}

1. Even prior to the Sasanian quadripartite division of their empire (MP. Eranšahr), another political entity had adopted the name of a cardinal direction for itself. This is specifically the case for the issuers of a coin series, part of the Alkhan series, who called

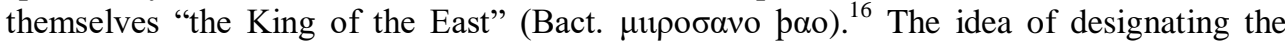
"East", the place of the rising sun, as the name of a political entity is quite intriguing. For one thing, claiming that one is the king of the "east" implicitly acknowledges that there is

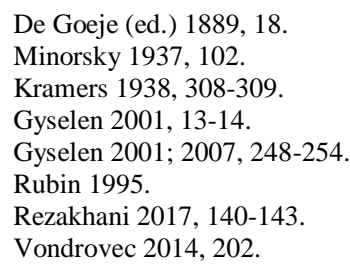


also a "west" with its own king, whatever and whoever that might be. ${ }^{17}$ Consequently, it seems obvious that the issuers of these series had an idea of themselves as controlling the eastern portions of a certain territorial whole. How this domain comes to embody the concept of Khurasan in the later Sasanian history and particularly in the early Islamic period is then the object of our enquiry.

2. Accordingly, understanding the place of the Alkhans as a whole, and particularly the Alkhan "East" issues, is crucial in picturing the development of the concept of Khurasan. While older scholarship in general referred to the entire class of post-Kushan conquerors of Transoxiana and Bactria as "the Hephthalites", the King of the East issues in fact belong to the Alkhan emissions and are clearly distinguished in modern scholarship from the "genuine Hephthalites". ${ }^{18}$ Indeed, it is indisputable that "genuine" Hephthalites are purely those whose coins, using the coins and coin style of Sasanian Peroz (459-484), bears the countermark $\varepsilon \beta(0) \delta \alpha \lambda o$ in Bactrian. The coin evidence also suggest that the Hephthalites kept themselves purely to the region of northern Hindu-Kush, eventually advancing to parts of Transoxiana (Menander Protector, Fragment 9.1) and further east to the Takla Makan desert. ${ }^{19}$ This is then widely used to separate the activities of the Alkhans and the Nezak, active to the south of the Hindu-Kush, from those of the "genuine" Hephthalites to the north, and to unburden the term "Hephthalite" from representing the entire "Iranian Huns" group. $^{20}$

With our increasing understanding of the Hephthalite political system in Bactria as an urban culture (Procopius, Wars, I.3), differentiating the invading forces of the Alkhans from the "genuine" Hephthalites is perhaps a useful corrective (fig. 1). ${ }^{21}$ This differentiation helps to disabuse historians of the notion that the activities and military conquests of various groups, including the Alkhans, in the $5^{\text {th }}$ and $6^{\text {th }}$ centuries were somehow centrally organized and executed by a collective "Hephthalite" entity. In considering the transition from the Kidarite dominance to Hephthalite control north of the Hindu-Kush, this is indeed crucial. However, over-stressing this point can also lead to active disregard for the close relationship between historical events that affected the entirety of the region from Transoxiana to northwest India, a point that a further inquiry about the East series can help illustrate. In the following section, we will consider the

17 This is the reason for my use of the term East Iran to designate the entire region that emerges out of the territories united by the Kushans in the earlier centuries. I suggest that East Iran here designates the political and cultural entity that develops to become the nucleus of the early Islamic "Persianate World," namely the Khurasan under discussion here. Through this usage, the designation Iran is taken out of its exclusive use either in the sense of the modern nation-state, or the late antique Sasanian Ërānšahr, both of which assume a necessarily "western" center for the political and cultural unit of Iran

18 See Kuwayama 1999. The distinction is made explicitly with the coin issues, first established by Göbl 1967 and followed by numismatists such as Vondrovec 2014, and historians like de la Vaissière 2007b. See below for further discussion of this and its implications for historiography.

19 Kuwayama 1999, 38.

20 We owe the grouping of the Iranische Hunnen coins into Kidarites, Alkhans, Hephthalites, and Nezak to Göbl and his monumental work on these coins, Göbl 1967, now continued by Pfisterer 2013 and Vondrovec 2014.

21 All illustrations from das Antlitz des Fremden are taken from the project's online portal (http://pro.geo.univie.ac.at/projects/khm/) and are used with kind permission. Illustrations from the Classical Numismatic Group (CNG) are taken from their website (www.cngcoins.com), with kind permission. 
relationship between the Hephthalites and the Alkhans and the utility of the famous Schøyen Copper Scroll inscription in placing the two in relation with each other.

\section{THE SCHØYEN COPPER SCROLL AND ITS GEOGRAPHICAL CONTEXT}

1. In one of the more sensational discoveries of primary material about the history of east Iran, an inscription on a copper scroll, dedicating a Buddhist stupa in Tālagānika, and naming several donors at the end of the $5^{\text {th }}$ century CE, surfaced in a private Norwegian collection. $^{22}$ The text of the inscription is in Sanskrit and includes several sutras, as well as a dedicatory segment providing the names of several donors, making it a valuable historical source. The majority of these donors are known to us from either the Bactrian Economic Documents (henceforth $\mathrm{BD})^{23}$ or various coin issues. ${ }^{24}$ The dedication part of the inscription's translation is as follows:

(33-39) In the sixty-eighth year on the seventh day of the bright half of the month Kārttika [corresponding to October-November]: On this day this caitya of the Realized One containing relics (dhātugarbha) was established by:

1. the lord of a great monastery (mahāvihārasvāmin), the son of Opanda, the Tālagānika-Devaputra-Șāhi, ...,

2. together with [his] father Opanda,

3. together with [his] wife, the daughter of the Sārada-Șāhi, [named] Buddh. ...,

4. together with the mistress of a great monastery Arccavāmanā,

5. together with [her] father Ho..gaya,

6. [and] with [her] mother, the queen (mahādev $\bar{\imath})$...,

7. together with the spiritual friend (kalyānamitra), the religious teacher (ācārya)

Ratnāgama,

8. together with the great șāhi (mahāṣāhi) Khīṇgīla,

9. together with the god-king (devarāja) Toramāna,

10. together with the mistress of a great monastery Sāsā,

11. together with the great Șāhi Mehama,

12. together with Sādavīkha,

13. together with the great king (mahārāja) Javūkha, the son of Sādavīkha; during the reign of Mehama. ${ }^{25}$

2. From those named above, Khīngīla, Toramāna, Javūkha, and Mehama - who is named twice - are known from their coins, as well as textual evidence of their presence in various parts of the Hindu-Kush region and northern India. Geographically, Melzer locates Tālagānika, the place of the monastery and the domain of the Tālagānika-Devaptura-Șāhi ("the Divine Son, the King of Talagān"), in northern Afghanistan, perhaps the city of

Melzer 2006.

Sims-Williams 2001; 2007.

Vondrovec 2014, 159-226.

Melzer 2006, 274. 
Talaqan $^{26}$ in eastern Bactria/Tukharistan, east of Qunduz. ${ }^{27}$ This identification, and the name of the authorities all of whom issued coins in the "Alkhan" series, already presents us with a challenge in contextualising the inscription.

The first response to this challenge was by Étienne de la Vaissière who, in an influential note, suggested that the identification of Tālagānika as Tālaqān needs to be abandoned. ${ }^{28}$ His suggestion for a replacement is the small town of Talagang in the Salt Range. ${ }^{29}$ The poignancy of de la Vaissière's arguments, and his reasoning - despite his own careful caution - has been influential enough that the suggestion has been taken as definitive, with the result that most subsequent publications have adopted this idea. In fact, de la Vaissière himself offers generous points of dispute with his own argument, including the presence of Iranian names, as well as the Buddhist context of the inscription. ${ }^{30}$ So below, I shall pick up some of de la Vaissière's doubts and elaborate on the issue.

3. De la Vaissière's suggestion seeks to persuade us to abandon the idea that the inscription could be a produced anywhere Bactria, or even refer to a Bactrian locale. His reasoning essentially consists of two main points: ${ }^{31}$

1- That we have to distinguish between the Alkhans in southern Hindu-Kush/India and the Hephthalites in the north (as suggested above and elsewhere).

2- That the context of the inscription is purely "Indian" and does not show any Bactrian influence. This would then make it necessary for us to look outside Bactria/Tukharistan in order to identify Tālaqānika.

In order to support these two suggestions, the author provides evidence from the Alkhan coin series (fig. 2), as well as the account of the Buddhist traveller, Song Yun from $520 \mathrm{CE}$. In the first instance, de la Vaissière posits that considering Alkhans and Hephthalites to be related would compel us to equate Khingila with Axšunwar, the Hephthalite king who in 484, defeated and killed the Sasanian king of king Pēroz. ${ }^{32}$ By correctly pointing out that Khingila, as well as Javūkha and Toramāna, only appear in an "Indian" context, de la Vaissière then leads us to his own solution, that the donors in the list need to be located in a southern Hindu-Kush/Indian context, and thus in the Salt Range town of Talagang. We will pick up this issue further below, but at this point, it helps to remember that apart from Khingila, Javūkha, and Toramāna, the main authority in the text, in whose domains the

On Talaqan, see Markwart 1931, 80.

27 As Sims-Williams has pointed out in his note - quoted in Melzer 2006, 256 - there are two locations known as Tälaqān in the vicinity of Balkh. The better known location is the one of our concern here, while a lesser known town to the west of Balkh is also known under this name. In Hudūd al-Ālam, the more easterly town is "on the frontier of Gūzgānān and belongs to its king" (Minorsky 1937, 107).

28 De la Vaissière 2007b.

29 De la Vaissière 2007b, 129

30 Reading the dedication segment of the inscription in the context of the rest of the inscription makes it quite clear that the entire text was composed in a Buddhist setting and that the dedication is in fact forming a continuous part of the text, following religious texts and being followed by them. See Melzer 2006, 255 for a list of the sutras quoted in the text.

31 De la Vaissière 2007, 128

32 Axšunwar is mentioned as the king of the Hephthalites by al-Tabari, I.874. Ferdowsi, in his normalising style, gives his name as Xušnawāz. For a discussion of possible etymologies, see Rezakhani 2017, 126-127. 
stupa is located, is in fact Mehama, and as a matter of fact, we do have enough evidence to place Mehama to north of the Hindu-Kush range.

But first, let us provide a rebuttal for the suggestion that the text is in fact purely Indian and does not bear any signs of Bactrian influence. In fact, the very name of the place, Tālagānika itself can only be explained through a Bactrian connection. As quoted by Melzer from a correspondence with Nicholas Sims-Williams, the suffix -ika is best explained by a reference to Bactrian -igo, which "forms adjectives from nouns, including ethnica from names of places and people". ${ }^{33}$ So, in fact the name of the place, even if it is Talagang in the Salt Range, has been rendered in the Sanskrit text with a Bactrian suffix, establishing a Bactrian connection indeed.

4. To return to the suggestion of distinguishing between the Alkhans and the Hephthalites in a strict sense, as asserted by de la Vaissière, we must consider the consequences of such distinction for historical purposes. In the present case, the distinction in fact forces a reading on the Schøyen scroll that is not necessarily supported by the text. The proposition, instead of being based on the text at hand, is prompted by a concern that positing any connection between the two group would necessarily mean assuming a 'unity' between them, across the Hindu-Kush. This, in de la Vaissière's reckoning, would presuppose some manner of unified rule, requiring, for example, the identification of Khingila with Axšunwar, the Hephthalite ruler who defeated Pērōz in $484 .{ }^{34}$

However, there is in fact no reason to be concerned with such assumptions or equations when considering the history of the region in the late $5^{\text {th }}$ and early $6^{\text {th }}$ centuries. A case in point is the assumption that the donors mentioned were contemporaries, an idea initially suggested by Melzer who proposed that this would require a reassessment of Alkhan chronology. ${ }^{35}$ However, as de la Vaissière mentions, ${ }^{36}$ there is no need to assume that all the mentioned donors were in fact contemporary. The text seems to only mention "the lord of a great monastery (mahāvihärasvāmin)," his wife Buddh... (incomplete name), and most importantly Sāhi Mehama, during whose reign the dedication was made, as the persons actually living and perhaps present. The rest of the donors, including the three mentioned by de la Vaissière as having only an Indian context, are in fact not mentioned to be present or even alive. Consequently, there is no reason to assume that the donors to a monastery, making donations at different times, were even contemporaries, let alone acting in unity or within the context of political alliances.

5. We would perhaps never know the identity of the "Tālagānika-Devaputra-Șāhi" or his wife, but the mahāsanhi Mehama, as is has been pointed out, is relatively well-known from other sources. He is originally introduced to us in a Bactrian document as "Meyam, the king of the people of Kadag, the governor of the famous (and) prosperous king of kings Peroz" (BD, 2007, docs. "ea" and "ed"). Document "ea" is dated to the year 239 (year 461 $\mathrm{CE}$ ), and Document "ed" is dated either 242 or 252 , respectively either 465 or $475 \mathrm{AD}$. In the latter case, "ed" would be placed after Peroz' first defeat at the hand of the Hephthalites

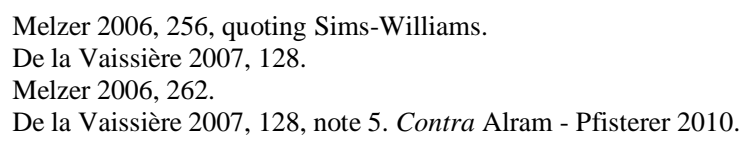


in 474 and perhaps show Mehama's continued fealty to the disgraced Sasanian king of kings. Apart from the dating, the Kadag people, and their territory of Kadagstan (mentioned in BD 2012, doc. "T", dated 478) were most likely located in eastern Bactria, in the high and middle valleys of Qunduz-Ab, quite close to Talaqan. ${ }^{37}$ These sources then would put Mehama's territory to the north of the Hindu-Kush and eastern Tukharistan.

Mehama, or Meyam, is also known from his coin production in both gold and silver. ${ }^{38}$ Significantly, his coins bear both Bactrian and Brahmi inscriptions and "according to numismatic methodology it is likely they were not only struck at the same place but also that the coin dies were manufactured by the same person". ${ }^{39}$ Stylistically, the silver issues of Mehama are within the Alkhan coin series, and are thus attributable to the area south of the Hindu-Kush. His gold issues, type 84A, however, bear some characteristics of the dinars carrying the name of Kidara. ${ }^{40}$ The type 84 of Kidara were found mostly in the Buddhist site of Tepe Maranjan in the Kabul region, along with coins of Sasanians Shapur II, Ardashir II, Shapur III, as well as a dinar of Kushano-Sasanian king, Wahram $6 .{ }^{41}$ As explained by Vondrovec, there is a high possibility that these coins were issued in the "Eastern" mint of the Sasanians, provisionally located in Kabul by Göbl.

Based on historical reasons, Vondrovec ${ }^{42}$ doubts that the dinars of Mehama (fig. 3) could have been issued in the city of Balkh, in the area of the supposed control of the Hephthalites. Proceeding from this, he then suggests that «the Alkhan were a confederation rather than a monolithic empire, but as of now we have insufficient proof for thus hypothesis». ${ }^{43}$ Despite the fact that the hypothesis sounds true enough, it is yet another example of historical suppositions forcing a particular reading on the available sources, this time the numismatic records.

6. The above then leads us back to the group of Alkhan style coin issues labeled the "Eastern" Alkhan by Vondrovec and bearing the Bactrian inscription of $\mu$ upo $\alpha \alpha v o$ pao (miirosano šao) which can be translated as "the King of the East". 44 Among the issuers of the "Eastern" coins is a certain ruler named Adomano whose coins include gold, silver, and copper issues, all bearing the title of the King of the East. Adomano is also mentioned in the Schøyen Copper Scroll inscription among the four authorities who dedicated the foundation of a stupa. A second donor of the stupa named on the Schøyen scroll is Javūkha, whose coins too bear the inscription that marks him as the "King of the East". ${ }^{45}$ While this does not place Mehama in a southern Hindu-Kush context, it still provides the possibility that the area of Mehama's rule around Qunduz/Tālaqān was in communication with the

37 Inaba $2010,447$.

38 See Vondrovec 2014, 142-145 for his gold issues and Vondrovec 2014, 187-190 for the silver issues and in depth discussion.

39 See Vondrovec 2008, 29. The name Meyam, Bact. Mүı $\mu$ o (or the shortened version $\mu \eta$ ) also appears on two seals, AA 6.3 \& AA 6.4 (Lerner - Sims-Williams 2011, 82-83). The crown depicted on the seals, however bears no resemblance to the crown of Mehama on the coins.

Vondrovec 2014, 143.

Vondrovec 2014, 143.

Vondrovec 2014, 202.

5 Vondrovec 2014, 204-207; Melzer 2006, 261-262. 
Kabul and Peshawar region further south and southeast through another way, perhaps a route which did not pass through the areas of Hephthalite control.

If we reconsider the strict assumption that the political division between the "Alkhan" and "Hephthalite" coin authorities would have meant a complete separation between the two polities, as de la Vaissière, and Vondrovec following him, maintain, ${ }^{46}$ we might be able to contextualize these coin issues, and the Schøyen scroll, in a different manner. This is specifically the possibility that an area to the east of Tukharistan, perhaps the region of Qunduz and Tālaqān, could have had direct contact with the regions of Kabul and Peshawar. This would present an alternative for the connections between the Alkhans with polities north of the Hindukush. Here, we return to the scene set up by the Schøyen scroll and can now draw a different picture of the region's political and social setting, and create a less segregated picture of the period.

\section{THE ALKHAN KINGS OF EASTERN TUKHARISTAN?}

1. By returning to Melzer's original location of Tālagānika as Tālaqān in eastern Tukharistan, a new view of the history of the region emerges in the contexts of both Sasanian, and local, histories. The successful campaigns against the Kidarites that allowed Pērōz (459-484) to build on the successes of his grandfather Vahram V (420-438) was supported locally by rulers such as Meyam who named himself the "governor of king of kings Peroz" while maintaining local authority as "the King of the People of Kadag". ${ }^{47}$ This hierarchy is completely consistent with established patterns of authority in world history and is likely presenting the formation of local, secondary states. ${ }^{48}$ The location of Tālaqān, across the mountains to the north of Kabul/Kapisi, puts it not only in eastern Bactria, but also close to the zone of early Alkhan power in the east. At the same time, Chinese sources tell us that Hephthalite authority in the sixth century extended as far east as the Takla Makan desert, which would indeed include the area of eastern Tukharistan. ${ }^{49}$

Considering the dating of the Schøyen scroll to $492 / 493 \mathrm{CE},{ }^{50}$ which is, despite the problems of equating it with the Laukika Era, generally accepted, the rule of Mehama gains

46 Of course, the main proponent of this was Shoshin Kuwayama, for which see, among others, Kuwayama 1999, 37-40 who proposes that there were no Hephthalties in Kapisi, Bamiyan, or Zabul, south of the HinduKush. A strict separation of the two would lead us to look for "conflicts" - as Vondrovec indeed looks for and does not find (Vondrovec 2014, 143).

47 Peroz has previously asked for help from the Hephtalites against his brother, Hormizd III (al-Tabari, I.872) before ascending the throne in 459 (Daryaee 2009, 24). While Meyam/Mehama is not explicitly mentioned his general association with Peroz is evident from the Bactrian documents ea and ed. Perhaps this alliance needs to be considered as part of the general alliance of Peroz with the Hephthalites, which could have included Mehama before the ascent of Hephthalites to power and the need for Mehama to find new, ie Alkhan, allies.

48 I do not wish to enter the discussion of "Iranian Feudelism" here, the classical study of which is Widengren 1969. A new work on the subject in the Seleucid period perhaps illuminates a few aspects of competing authorities in the wider Middle Eastern context (Engels 2011). In the European context, this is obviously well studies, with Hurt's study of Louis XIV (Hurt 2002) and Henshall's revisionism setting up a new tone (Henshall 2014). For the Iranian context, perhaps, the title of Shahanshah itself is the most illuminating, for which see Shayegan 2011, 228-292.

49 Kuwayama 1999, 38-39.

50 Melzer 2006, 263-264. 
a new meaning. The year 492/493 places the foundation of the Stupa, and the rule of Mehama as an independent mahāsāahi, within the first period of the reign of Kavad I (488496/498-531). This is the apogee of the Hephthalite rule in Bactria, to the west of Qunduz and Tālaqān, Mehama's territory. ${ }^{51}$ In this context, we can speculate that Mehama/Meyam, the former "governor" of Peroz, Kavad's father and the enemy of the Hephthalites, was quite naturally at odds with the rising power of the Hephthalites further west. As such, allying himself with an Alkhan authority further south in Kapiśi and providing patronage to a known Buddhist site, as well as issuing Alkhan style coins, would have been the natural course of action for Mehama/Meyam to show his alliance. This would also bring new meaning to the term "King of the East", as this "East" naturally suggests the existence of a "West" as well, it being the westerly territories of the Hephthalites in Balkh and beyond. Additionally, the discontinuation of the Mehama/ Eastern coin series ${ }^{52}$ and a shifting of the issues to those of Khingila and others in Gandhara and Uddyana are evidence for the conquest of this "Eastern" kingdom by the Hephthalites. It is in fact after 492/493, and in the sixth century, that we can talk about the separation of Alkhan and Hephthalite zones of control, as mentioned by Chinese sources and taken as a fact by Kuwayma, de la Vaissière, Vondrovec. Mehama, and the rest of the Eastern series, in fact show a short period of rule in eastern Tukharistan by forces allied to the Alkhans, later snuffed by the rising power of

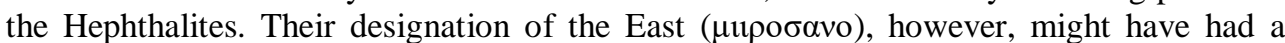
longer life in the geopolitics of the region, as we see below.

\section{SASANIAN KHURASAN}

1. The fate of the Miirosan kingdom, of course, cannot be fully gazed, except for its loss to the growing power of the Hephthalite state and its expansion to the east. Subsequently, following the Western Türk destruction of the Hephthalite power in the latter half of the sixth century, parts of the former Hephthalite territories south of the Oxus River fell to the Sasanian, at least temporarily. ${ }^{53}$ If we assume that the Hephthalite territories by this time encompassed the former Miirosan as well, the Sasanian control of the area coming to embrace the designation as well.

In the sixth century, the reforms of Khosrow I (531-579), perhaps started at the time of his father Kavad I (488/494-527), included a major overhaul of the empire's military structure, in essence dividing the defenses among four different Generals or Ispahbids, each

51 See Rezakhani 2017, 125-140 for a general history of the Hephthalites. Details of Hephthalite rule in the region are not well known due to a lack of sources, although the famous passage of Procopius of Cesarea (Wars I.3, vv. 1-7) marking them as "White Huns" has been instrumental in connecting them to other sources such as the Spēd Xyōn mentioned in Zand-i Wahman Tasn 2.58-59 (Cereti 2010, 64-65).

52 Vondrovec 2014, 208-209 includes a series of Anonymous "Eastern Alkhan" which can be contemporary or subsequent to the Eastern Alkhan issues previously mentioned. The rest of the Alkhan coinage, however, are continuing the style that earns the name of "Alkhan in India" (Vondrovec 2014, 211-219).

53 See Sinor 1990 for the history of the Western Türk empire and its expansion. Grenet 2002 provides a very interesting, if synoptic, view of the greater Bactria/Tukharistan region after the fall of the Hephthaltie empire and the continuation of sub-Hephthalite kingdoms in the region. Rezakhani 2018 identifies the battle in which the Western Türk vanquish the Hephthalites. 
assigned to a cardinal direction and ruler by a Spāhbed or general. ${ }^{54}$ The names, Xwarāsān (Sun-rise/East), Xwarawarān/Xwarōfrān (sun-down/West), Nēmrōz (Mid-day/South) and Abāxtar (Behind/North) ${ }^{55}$ all point to various positions of the sun. Among these, the name of Kust-i Xwarāsān/Khurasan ${ }^{56}$ (fig. 4) is a direct parallel to Bactrian Miirosan, the place of the "sunrise," or the east, although there is no way for us to tell if this was the inspiration for the naming of the three other generalships as well. The he division most likely happened after the Sasanians managed to control the former Hephthalite territories after the victories of the Western Türk.

Apart from the evidence of the seals, the clearest reference we have to the position of the Spāhbed is in reference to the murderer/executioner of Khosrow II, Mihr-Hormuz, the son of Mardānšāh, who «was the Fādhūsbān over the province of Nīmrūz and one of Kisrā's most obedient and trusty retainers.» ${ }^{57}$ The rest of the Kusts are mentioned in the Geographie of pseudo-Moses of Khorene, where Khurasan most significantly does not include the regions of Sistan and Zabulistan, which are included in Nēmrōz. ${ }^{5}$

The name of Xwarāsān also appears prominently in the famous Shahristānī-hā $\bar{l}$ $\bar{E} r \bar{a} n s ̌ a h r$ "the Book of the Provincial Capitals of Ërānšahr" ( $\breve{\mathrm{S}} \overline{\mathrm{E}}) .{ }^{59}$ The final redaction of the text most likely occurred in the late eighth century, but it in fact mainly enumerates the divisions of the Sasanian Empire and a few areas outside of it..$^{60}$ The description starts from the east, the Kust $\bar{\imath}$ Xwarāsān, and includes Samarkand (in Transoxiana), Sugd $\bar{\imath}$ Haft $\bar{A} \bar{s} y \bar{a} n$ (unclear, but in Transoxiana), Nawāzag in the Balkh area, the Shahristan of Khwarazm (presumably Jurjaniya of the Muslim sources), Marwrōd (Islamic Marw-ar-rūd), Marw (Islamic Marw-ī Šāhìjān), Herat, Pošang, Tūs, Nēshapur, Kāyēn (Qāen), Dehestān of Gurgān, Qumis, and the Five Cities built by Khusrow I. ${ }^{61}$

It is particularly in the early post-Sasanian documents that we see a proliferation of the name of Khurasan as the designation for the rule over the eastern quarter. A document dated to the year 503 of the Bactrian era $(727 \mathrm{CE})$, mentions a "Prince of Khurasan," Bact.

54 See Gyselen 2001 for a discussion of the sigillographic evidence for this quadripartite division known already through historians such as al-Tabari. The title Spāhbed is ubiquitous on these seals, but other titles should also be considered, including hujadag-Khusrō ("good-omened/augured of Khosrow," as opposed to hujadagOhrmaz) which attributes certain seals to the period of Khosrow I (531-579) (Gyselen 2007, 50).

55 Abaxtar or North, because of its association with demonic forces, was often replaced with Ādūrbādagān (as it is mentioned on the seals, Gyselen 2007, 48), which probably was a clearer indication of its actual territorial extent.

56 Markwart 1931, 25.2 for the explanation of Kust as "side" and also the Xwarāsān as "sun-rise."

57 Al-Tabari I. 1058 (Bosworth 1999, 395).

58 Marquart 1901, 1-136, with the description of Khurasan, 47-93. Sakistan and Zabulistan are discussed as part of the Quarter of the South/Nēmrōz (35-40). This is also consistent with the later use of the name of Nīmrūz as the territory of the later Saffarid maliks (Bosworth 1994).

59 Daryaee 2002; Markwart 1931.

60 Daryaee 2002, 1-7.

$61 \breve{S} E$ 20-20, Daryaee 2002, 18-19, see extensive commentary by Markwart 1931, 24-59. The five cities, as Markwart points out (Markwart 1931, 58-59) "are wholly unknown." I do wonder whether the "Five Cities" is not an MP translation, quite literal, of Panjkent, the famous Sogdian city to the east of Samarqand, and if these are in fact names of its five constituent parts. I await the publication of MK manuscript, including the text of $\breve{S} \bar{E}$, by Almut Hintze later this year in order to check out certain details that might confirm or dismiss this idea. 


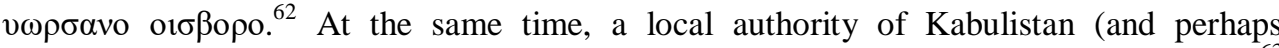
Zabulistan) issued coins on which he identifies himself as the "Tegin, Khurasan Shah". 63 These coins, in both silver and copper, are based on earlier Arab-Sasanian coin types and incorporate the usual Sasanian coin legends and their dating system follows that of the Yazdgirdi Era, mostly issued around $728 \mathrm{CE}$ and later. ${ }^{64}$ The title of $h w l$ 's' $n M L K$ ' is written in Pahlavi on types 329 and 208 of Tegin (fig. 5), while the Bactrian inscription simply marks the king as the Exalted King $\sigma \rho \mathrm{\tau} \tau \alpha \gamma \mathrm{iv}(\mathrm{o}) \mathrm{p} \alpha(v) \mathrm{v}$. The use of the title of the King of Khurasan, and the Pahlavi inscription, can perhaps be attributed to the strong local context of the term and its descent from Bactrian Miirosan in East Iran, or a direct adoption of the Sasanian title of the Spahbēd of Khurasan. ${ }^{65}$

Another occurrence of the term, still prior to the activities of Abu Muslim in 750 and beyond, is the mention of an Ispahbid of Khurāsān among the court records known as the Tabaristan Archive. This is a Middle Persian document to 728/729 CE which identifies an Ispahbid of Khurasan in the southern Caspian coast:

«(1) Māh Hordād abar sāl 77 rōz Xwar, mardān ī (2) Xwāst-Dēlān nām Hormiz pus, $\overline{1}$ az ān *Haspān-raz deh (3) ī pad xānag Dēl-Dēlān pad dar-espās î yazdān-bānag (4)

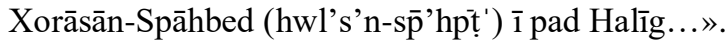

«Month Khordād in the year 77 day Xwar (728/729 CE), the people of XwāstDēlām by name, son of Hormiz, from that village of *Haspinn-raz, in the house of Dēldēlān, in the service of the General of the East, protected by the gods...». ${ }^{66}$

Assuming that Weber's geographical identification of Dēl $\bar{\imath}$ Dēlān as Deilam ${ }^{67}$ and as a district of Tabaristan ${ }^{68}$ is correct, ${ }^{69}$ the presence of an Ispahbed of Khurasan/East in the region of Tabaristan, with an agent in a village in the region of Deilam/Daylam, is most unusual. We know that in later periods, the rulers of the Tabaristan called themselves by the name of Ispahbid (from MP Spāhbed) and continued to rule the area until the Timurid period $\left(14^{\text {th }}\right.$ century) ${ }^{70}$ It is also worth remembering that Ibn Khurradadbih, even in the ninth century, names an Ispahbid - incidentally named Badusban - and possibly related to the Dabuyid Ispahbids, as the ruler of Khurasan.

62 Sims-Williams - de la Vaissière 2011, UV2 and commentary, 40

63 Vondrovec 2014, 538-543.

64 Vondrovec 2014, 537-539

65 As Vondrovec 2014, 537 points out, however, there is no direct link between the coins of the Alkhan East series and the coins of Tegin, Khurasan Shah. Perhaps we should consider the inscription on Tegin's coins in the context of the use of Pahlavi, already in the fifth century, by the Nezak Shah rulers of Kabul and Zabul (Vondrovec 2014, 449-500).

66 Weber 2017, 155, doc. tab. 17; Macuch 2017, 189.

67 See Markwart 1931, 126-127 for how Deilam is traditionally understood.

68 Tabaristan itself is traditionally part of the Kust of Adurbādagān, Markwart 1931, 129-135.

69 Weber 2017, 131.

70 See Ibn Isfandiyar 90ff, also Bosworth 1996, 162-165 were the Dabuyid and Bawandid Ispahbads (sic.) are listed. 
In the first half of the seventh century and before the rise of Abu Muslim and his Khurasani army, then several authorities claimed the rule of Khurasan. While the ruler of Tabaristan identifies himself as the Spāhbed of Khurasan, the ruler of Khish thinks of himself as the "Prince" of Khurasan, ${ }^{71}$ and the Tegin claims the title of the "King" (Shah) of Khurasan. All these sources date to the third and fourth decades of the seventh century and are very active signs of the popularity of the concept of Khurasan prior to the rise of Abu Muslim in 750.

\section{CONCLUSION}

Our knowledge of the regional history of the Sasanian and early Islamic empires is quite limited. The proliferation of geo-political designations such as Khurasan in the medieval period, are useful in understanding the regional history and its interactions with the larger imperial politics and administration. However, the history of the development of such concepts are often vaguely known, and many modern studies use anachronistic measures for understanding these territorial and cultural designations. With our increasing knowledge of the political geography of the "Eastern" provinces of the Sasanian Empire, and its development as a region in the periods before Sasanian domination, a study of Khurasan appears necessary and timely. Through such study we can begin to understand the rise of the region as a source of power in the medieval Islamic world and the way its shaped polities from the Abbasids to the Samanids, Seljuqs, Mongols, and the Timurids.

This article presents a survey of the available material for the history of what it calls East Iran. This designation is not a way of possessing the region as part of a modern "national" concept, but as an independent cultural zone which in the medieval period which was itself the core of the concept of Iran or what some modern historians call the Persianate World. By tracing the idea of East Iran through Bactrian Miirosan and Middle Persian $X w r \bar{a} \bar{a} n$, the article suggests that Khurasan as the core of the medieval Persianate World was in fact a long time in the making. In both its cultural and political aspects, the Khurasan of the Islamic period was the product of a long process of state-creation, starting with the forging of a territorial unity under the Kushans and proceeding through the Kidarite, Hephthalite, and Sasanians periods. The immediate precedence of the Abbsid Khurasan, however, needs to be sought in the rise of the concept of Khurasan as a coherent political unit in the early Islamic period and in the competing claims of the Ispahbids, Princes, and Kings who claimed the title of rule in the area.

71 Sims-Williams - de la Vaissière 2011, 43. 


\section{REFERENCES}

Alram, M. - PFisterer, M.

2010 Alkhan and Hephthalite coinage: M. Alram - D. Klimburg-SAlter - M. Inaba - M. PFisterer (eds.), Coins, Art and Chronology II. The First Millenium C.E. in the IndoIranian Borderlands (Österreichische Akademie der Wissenschaften. PhilosophischHistorische Klasse Denkschriften, vol. 412), Vienna 2010, pp. 13-38.

BENNISON, A.K.

2014 The Great Caliphs: The Golden Age of the 'Abbasid Empire, New Haven 2014

BosworTh, C.E.

1994 The History of the Saffarids of Sistan and the Maliks of Nimruz: (247/861 to 949/1542-3), Columbia Lectures on Iranian Studies 8 (1994), Costa Mesa - California - New York 1994.

1999 C.E. Bosworth (Translator), The History of Al-Tabari: The Sasanids, the Byzantines, the CERETI, C.G Lakmids and Yemen, Albany (NY) 1999.

2010 Xiiaona- and Xyôn in Zoroastrian Texts: M. AlrAM - D.E. KLIMBURG-SAlter (eds.), DANIEL, E.L. Coins, Art, and Chronology II, Vienna 2010, pp. 59-72.

1979 The Political and Social History of Khurasan under Abbasid Rule, 747-820, Mineapolis 1979.

1995 The Emergence of the 'Abbasid Autocracy: The Abbasid Army, Khurasan and Adharbayjan, Mineapolis 1995.

DARYAEE, T.

2002 Šahrestānīhā İ Érānšahr: A Middle Persian Text on Late Antique Geography, Costa Mesa 2002.

2009 Sasanian Persia: The Rise and Fall of an Empire, London 2009.

De GoEJE, M.J. (ed.)

1889 Al-Masalik Wa Al-Mamalik (Bibliotheca Geographorum Arabicourm), Leiden 1889.

ENGELS, D.

2011 Middle Eastern 'Feudalism' and Seleucid Dissolution: K. ERICKSON - G. RAMSAY (eds.), GIBB, H.A.

1923 The Arab Conquests in Central Asia, London 1923.

GÖBL, R.

1967 Dokumente zur Geschichte der Iranischen Hunnen in Baktrien und Indien, Vol. 2, Wiesbaden 1967.

GRENET, F.

2002 Regional Interaction in Central Asia and Northwest India in the Kidarite and Hephthalite Periods: N. Sims-Williams (ed.), Indo-Iranian Languages and Peoples (Proceedings of the British Academy 116), Oxford 2002, pp. 203-224.

GYSELEN, R

2001 The Four Generals of the Sasanian Empire: Some Sigillographic Evidence, Rome 2001.

2007 Sasanian Seals and Sealings in the A. Saeedi Collection (Acta Iranica 44), Leuven 2007.

HENSHALL, N.

2014 The Myth of Absolutism: Change \& Continuity in Early Modern European Monarchy, London 2014.

HURT, J.J.

2002 Louis XIV and the Parlements: The Assertion of Royal Authority, Manchester 2002. 
IBN ISFANDIY AR, $M$.

1320 ABBAS IQBAL (ed.), Tarikh-e Tabarestan, Tehran 1320.

INABA, M.

2010 From Kesar the Kabulshah and Central Asia: M. Alram - D. Klimburg Salter - M. InABA - M. Pfisterer (eds.), Coins, Art and Chronology II: The First Millennium C.E. in KENNEDY, H. the Indo-Iranian Borderlands, Vienna 2010, pp. 443-455.

1986 The Prophet and the Age of the Caliphates, New York 1986.

KRAMERS, J.H. (ed.)

1938 Surat Al-Ard (Opus Geographicum) (Bibliotheca Geographorum Arabicourm), Leiden 1938.

KUWAYAMA, S.

1999 Historical Notes on Kāpiśī and Kābul in the Sixth-Eighth Centuries: Zinbun 34.1 (1999), pp. 25-77.

LERNER, J.A. - N. SIMS-WILLIAMS.

2011 Seals, Sealings and Tokens from Bactria to Gandhara: (4th to 8th Century CE), Vienna 2011.

MACUCH, M

2017 Pahlavi Legal Documents from Tabarestan on Lease, Loan and Compensation: The Juristic Context: R. Gyselen (ed.), Sasanian Coins, Middle-Persian Etymology and the Tabarestan Archive (Res Orientales XXVI), Bures-sur-Yvette 2017, pp. 165-195.

MADELUNG, W.

1998 Baduspanids: Encyclopaedia Iranica. Vol. III, Fasc. 4, pp. 385-391 (online version 2011; accessed 15 October 2019)

MARIN-GUZMAN, R

1994 The 'Abbasid Revolution in Central Asia and Khurāsān: an Analytical Study of the Role of Taxation, Conversion, and Religious Groups in Its Genesis: Islamic Studies 33.2/3

MARKWART, J (1994), pp. 227-252.

1931 A Catalogue of the Provincial Capitals of Eranshahr:(Pahlavi Text, Version and MARQUART, J. Commentary), Rome 1931.

1901 Érānšahr nach der Geographie des Ps. Moses Xo59renacci: mit historisch-kritischen kommentar und historischen und Topographischen excursen, AKGW-Götingen, Phil.Hist. Klasse III, Berlin 1901.

Melzer, G. (in collaboration with L. Sander)

2006 A Copper Scroll Inscription from the Time of the Alchon Huns: J. BRAARVIG (ed.), Manuscripts in the Schфyen Collection (Buddhist Manuscripts 3), Oslo 2006, pp. 251-314.

MINORSKY, V. (Translator)

1937 Hudud Al 'Alam: The Regions of the World. A Persian Geography, 372 A.H. - 982 A.D., Oxford 1937.

PFISTERER, $\mathrm{M}$.

2013 Hunnen in Indien, Vienna 2013.

PROCOPIUS OF CAESAREA

RANTE, $\mathrm{R}$

History of the Wars I-II: the Persian War: H.B. DewING (Translator), Cambridge 1914.

2015 Greater Khorasan, History, Geography, Archaeology and Material Culture, Berlin Boston 2015. 


\section{REZAKHANI, K.}

2017 ReOrienting the Sasanians: East Iran in Late Antiquity, Edinburgh 2017.

2018 Shahnameh as a Historical Source, 1: The Türk and the Hephthalites: N. Foтооні (ed.), Holyfest.Org: Festschrift in Honor of Olga (Holly) Davidson on the Occasion of Her Sixty-Sixth Birthday, Boston 2018: Online.

RUBIN, Z.

1995 The Reforms of Khusro Anushirwan: A. CAMERON (ed.), States, Resources and Armies (The Byzantine and Early Islamic Near East 3), Princeton 1995, pp. 227-297.ShABAn, M.A.

1970 The 'Abbāsid Revolution, Cambridge 1970.

SHAYEGAN, M.R.

2011 Arsacids and Sasanians: Political Ideology in Post-Hellenistic and Late Antique Persia, Cambridge 2011.Sims-WiLLIAMS, N.

2001 Bactrian Documents from Northern Afghanistan, Vol I: Legal and Economic Documents (Studies in the Khalili Collection, Vol. I), Oxford 2001.

2007 Bactrian Documents from Northern Afghanistan, Vol. 2: Letters and Buddhist Texts, Vol. 3.2 (Studies in the Khalili Collection, Vol. II), Oxford 2007.

Sims-Williams, N. - DE LA Vaissière, É.

2011 A Bactrian Document from Southern Afghanistan?: Bulletin of the Asia Institute 25 (2011), pp. 39-53.

SINOR, D.

1990 The Establishment and Dissolution of the Türk Empire: D. SINOR (ed.), The Cambridge History of Early Inner Asia, Cambridge 1990, pp. 285-316.

DE LA VAISSIÈRE, É.

2007a Samarcande et Samarra: Élites d'Asie Centrale Dans l'empire Abbasside. Paris - Leuven 2007.

2007b A Note on the Schøyen Copper Scroll: Bactrian or Indian?: Bulletin of the Asia Institute 21 (2007), pp. 127-130.

DE LA VAISSIÈRE, É. (ed.)

2008 Islamisation de l'Asie Centrale (Studia Iranica 39), Paris 2008.

VONDROVEC, K.

2008 "Numismatic Evidence of the Alchon Huns Reconsidered." Beiträge Zur Ur-Und Frühgeschichte Mitteleuropas 50, pp. 25-56.

2014 Coinage of the Iranian Huns and Their Successors from Bactria to Gandhara (4th to 8th Century CE), Vienna 2014.

WEBER, D.

2017 Pahlavi Legal Documents from Tabarestan on Lease, Loan and Compensation: A Philological Study: R. GYSELEN (ed.), Sasanian Coins, Middle-Persian Etymology and the Tabarestan Archive (Res Orientales XXVI), Bures-sur-Yvette 2017, pp. 131-163.

WIDENGREN, G.

1969 Der Feudalismus Im Alten Iran: Männerbund-Gefolgswesen-Feudalismus in Der Iranischen Gesellschaft Im Hinblick Auf Die Indogermanischen Verhältnisse, Vol. 40, Wiesbaden. 

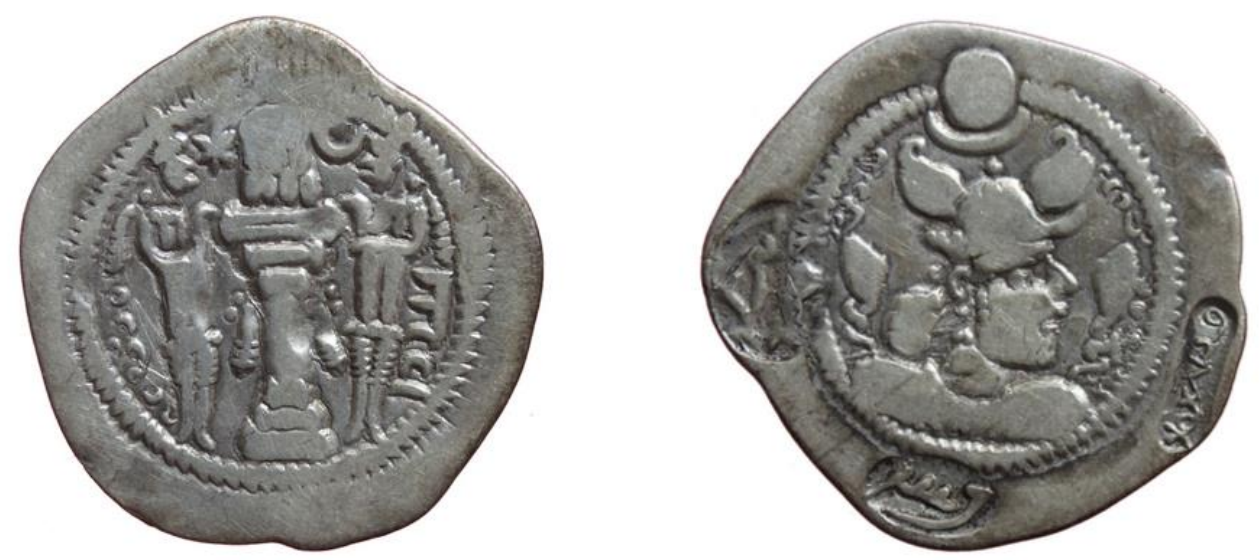

Fig. 1 - a "Genuine" Hephthalite issue, countermarked on a coin of Sasanian Pērōz (Photograph courtesy of das Antlitz des Fremden).
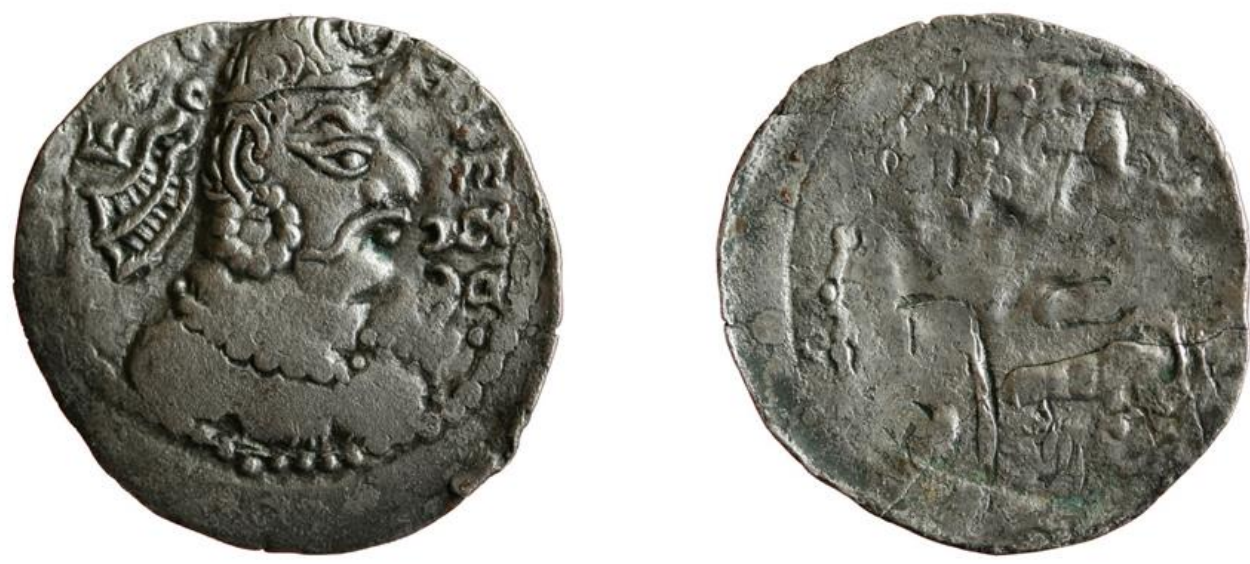

Fig. 2 - Alkhan "East" coinage: a coin of Javukha (Photograph courtesy of das Antlitz des Fremden). 

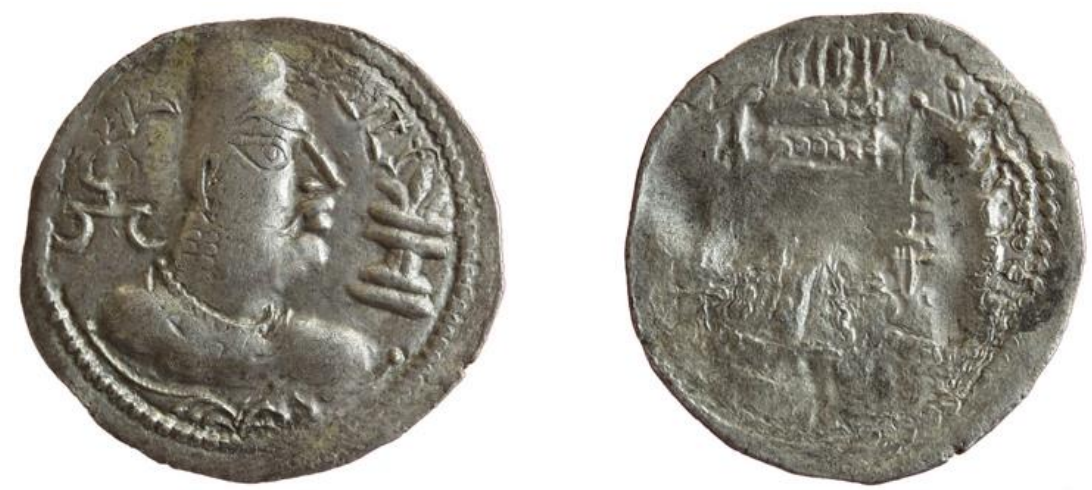

Fig. 3 - Silver issue of Mehama (Photograph courtesy of das Antlitz des Fremden).

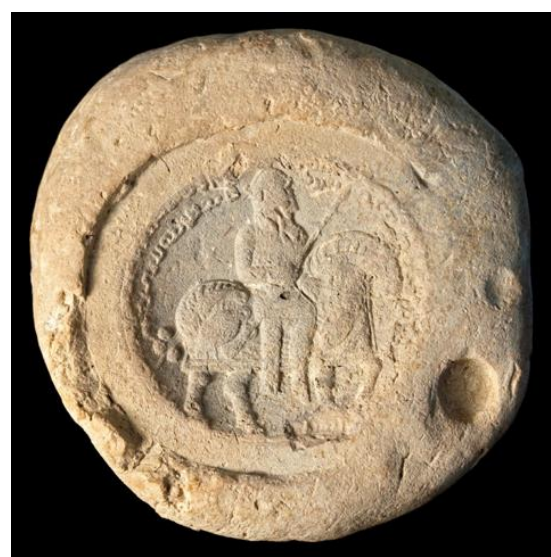

Fig. 4 - Sasanian seal-impression, attributed to the Spāhbed of Xwarāsān (Private collection).
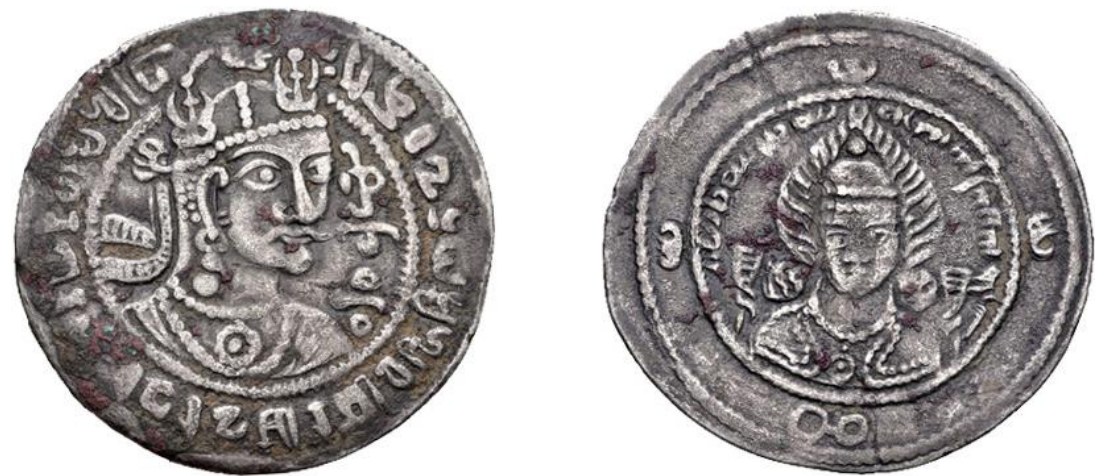

Fig. 5 - Coin of Tegin, Khurasan Shah (Classical Numismatic Group 390, Lot 381). 